Article

\title{
The Public Choice of Public Stadium Financing: Evidence from San Diego Referenda
}

\author{
Candon Johnson and Joshua Hall * \\ Center for Free Enterprise, West Virginia University, Morgantown, WV 26506, USA; cjohns77@mix.wvu.edu \\ * Correspondence: joshua.hall@mail.wvu.edu; Tel.: +1-304-293-7870
}

Received: 4 January 2019; Accepted: 19 March 2019; Published: 21 March 2019

\begin{abstract}
Local politicians and team owners frequently argue that the public financing of stadiums is important for local economic development. The sports economics literature, however, has largely found that new professional sport facilities do not generate any new net economic activity. We provide context to this literature by exploring the public choice in the public financing of stadiums. In 2016, San Diego had two ballot measures related to the San Diego Chargers. Measure C would allow officials to raise hotel taxes to pay for a new downtown stadium for the Chargers. Measure D would also raise hotel taxes, but explicitly prevented any money being spent on the Chargers. Both measures failed to receive $50 \%$ of the votes cast. We find that zip codes with a higher voter turnout were more likely to vote against both measures, highlighting the importance of the timing of referenda in limiting the ability of clearly defined groups, such as Chargers fans, to have a large influence on the voting outcome. Meanwhile, areas with more Trump voters were more likely to support higher taxes for the purpose of building the Chargers a new stadium.
\end{abstract}

Keywords: voting behavior; National Football League; Donald Trump

JEL Classification: D72; Z20

\section{Introduction}

Professional sports stadiums have been largely publicly funded in recent decades (Humphreys 2019). The public funding of stadiums is a topic of interest among economists and are of policy relevance, due to the large costs associated with building stadiums (Matheson 2019). The rationalization for public funding generally appears under the guise of economic growth, such as economic expansion and job creation. This growth does not appear, suggesting that the ability for professional sports to be a catalyst of economic growth has been overstated (Baade 1996). While professional sports are not an engine of economic growth, support for professional sports additionally comes from the potential social impacts. As stated in (Rosentraub 1996, p. 29), "Sports is too important a part of Western society for us to think that cities can exist without the teams and the events which define essential dimensions of our society and life." The public funding of stadiums has been partly responsible for stadiums returning to the city center, after decades of being located in suburban areas (Chapin 1999). The San Diego Chargers attempted to construct a stadium in downtown San Diego by securing public funding, through referenda included on the ballot during the 2016 US presidential election.

Professional sport stadiums are largely publicly funded infrastructure projects that benefit the owners and players, while providing no economic benefits to taxpayers (Baade 1996). The public funding of stadium construction, combined with the lack of evidence in favor of net economic benefits (Coates and Humphreys 2003a, 2003b, 2008), raises an important question: Why do voters support or reject public financing of professional sports stadiums? We provide insight into this 
question using a public choice analysis of votes on public financing for a new football stadium for the San Diego Chargers.

In 2016, on the same ballot as the US presidential election, the city of San Diego had two ballot measures related to the financing of a new convention center in San Diego and whether the San Diego Chargers of the National Football League would receive financing for a new stadium (Bonesteel 2016). These measures were known as Measure C and Measure D (San Diego Registrar of Voters 2018). Measure $C$ was a downtown stadium initiative that would have raised the hotel occupancy tax by six percentage points, primarily to fund a new convention center and a stadium for the Chargers (Garrick 2016). Measure D was a response to Measure C being placed on the ballot (McSwain 2016). While Measure D would have raised hotel taxes to possibly fund a new convention center, it was only only by five percentage points (Showley 2016). The biggest difference, however, was that Measure D explicitly prevented any public money being used for the construction of professional sports facilities (Anderson 2016). Both measures failed at the ballot box, with both measures receiving under 45 percent 'yes' votes (Bonesteel 2016).

These two separate ballot measures, presented to San Diego voters at the same time, provide a unique opportunity to better understand voter preferences with respect to public financing of sports stadiums. In doing so, we contribute to the scholarly understanding of voter support for public financing of sports stadiums (Ahlfeldt and Maennig 2012; Brown and Paul 1999; Coates and Wicker 2015; Friedman and Mason 2004). Our findings highlight the importance of the public choice literature on electoral timing (Anzia 2011; Dunne et al. 1997; Holcombe and Kenny 2008; Meredith 2009), given that we find that a higher voter turnout is associated with fewer 'yes' votes. Having these referenda on the ballot at the same time as a Presidential election almost certainly reduced the likelihood of getting a majority of cast votes for either measure.

Our brief empirical paper proceeds as follows. Section 2 provides additional information on the San Diego ballot measures. Section 3 discusses our data and empirical approach, which builds off the public choice and sports economics literature on referendums. We present our empirical results in Section 4 and conclude in Section 5.

\section{The San Diego Referenda}

Founded in 1960, the Chargers played in Los Angeles for one season before moving to San Diego (Nunn and Rosentraub 1997). The team began playing in Qualcomm Stadium, now called the San Diego County Credit Union Stadium, in 1967 (Peach 2004). With an aging stadium, ranked among the worst in the NFL (Chase 2015), the Chargers pushed for a new stadium in San Diego. During the 2016 US presidential election, two measures appeared on the ballot regarding a new stadium for the San Diego Chargers (Schrotenboer 2016).

Measure $C$ provided funding for a new stadium in downtown San Diego by raising the transient occupancy (i.e., hotel) tax six percentage points, from 10.5 to 16.5, with five-sixths of the fund being used for the new convention center and stadium (Schrotenboer 2016). A two percentage point assessment, which hotels charge to fund a tourism marketing district, would be eliminated (Lewis 2015). One-sixth of the tax increase would be placed into an existing San Diego Tourism and Marketing Fund. The tax increase would be decreased to three percentage points if the construction of the new stadium was not completed within two years, following the last home game in Qualcomm Stadium, or if all city bonds are re-paid, among other reasons. The stadium would seat 65,000 and be expandable to 75,000 ; the convention center would contain over 300,000 square feet of meeting space (Hazinski and Cotte 2016). The measure would fund $\$ 1.15$ of $\$ 1.8$ billion of the cost of stadium initiative for land acquisition, construction of the convention center, and construction of the integrated joint use portion. The remaining $\$ 650$ million would be allotted to the construction of the stadium, being privately funded by the Chargers. In addition to the $\$ 650$ million contribution, the Chargers would be required to give a 30-year commitment to play in the stadium, thus committing to the city of San Diego (Nelson 2016). 
Arguments given in favor of Measure C included: No new taxes imposed on San Diego residents, the city overseeing the stadiums design, construction, and operations, and jobs will be created (Nelson 2016). The amount of jobs created were claimed to include 17,000 during construction, as well as 3000 permanent jobs (Sklar 2016). Arguments against included: Taxes should be used for other purposes, worsening San Diego's parking and traffic situation, and hurting tourism in San Diego (Hazinski and Cotte 2016). Sports have been shown to worsen traffic conditions, and the new stadium would be moving into an already congested area (Humphreys and Pyun 2018). Also, large conventions, such as the San Diego Comic-Con, were opposed to the measure (Cate et al. 2016). The Comic-Con preferred an expansion of the current convention center in San Diego, instead of a new convention center in a different area of San Diego.

Measure D would utilize an increase in transient occupancy taxes to fund a downtown convention center, but not a stadium, prohibiting the use of public funds on construction of a new stadium without a public vote (Anderson 2016). Hotels with 30 or more rooms, recreational vehicle parks, and campgrounds would see an increase of five percentage points, while hotels with fewer than 30 rooms would see an increase of 3.5 percentage points (San Diego City Attorney 2016). The measure would also allow for the sale of Qualcomm Stadium to one or more colleges or universities in San Diego, or the San Diego River Conservancy. While a stadium was not to be funded by the measure, it would allow for a sports facility to be combined with the convention center. It could also permit a new facility to be built in Mission Valley, the area where Qualcomm Stadium was located.

Ultimately, both measures failed to convince a majority of voters that they should be passed. Measure C garnered only $44 \%$ support and Measure D also failed, with only $41 \%$ support (Garrick 2016). Across the city, however, there were very different vote totals, suggesting that some concerns (such as traffic) might have been more salient for some voters than others. With the measures failing, the Chargers found another option by moving to Los Angeles, beginning in the 2017 NFL season (Pelissero 2017). Following the completion of the Los Angeles Stadium at Hollywood park, the Chargers and Rams will share the privately-funded venue (Chavez 2018).

\section{Data and Empirical Approach}

To better understand why San Diego voters vetoed both measures related to the San Diego Chargers (and a new convention center), we employ an empirical median voter model (Holcombe 1989). This model has been used extensively, in the sports economics literature, to better understand the factors influencing public support for stadium financing and mega-events, such as the Olympics. For example, Ahlfeldt and Maennig (2012) showed that voting in Munich, Germany for an Allianz Arena exhibited a Not In My Backyard (NIMBY) character, where voters further away from the stadium construction site were more supportive. Coates and Humphreys (2006) and Horn et al. (2015) showed that voters in closer proximity to the stadium site were more supportive of the stadium being built. Coates and Wicker (2015) found that areas with high rates of unemployment tended to be in favor of putting in a bid for the Olympics.

As is typical in empirical median voter models (Hall and Karadas 2018; Matti and Zhou 2017), a linear regression is used with the percentage of voters that voted yes as the dependent variable. Measures $\mathrm{C}$ and $\mathrm{D}$ both had similar voting outcomes in aggregate, but are different at the sub-city level. The linear model estimated is:

$$
\text { VoterSupport }_{i}=\beta_{1} \text { Population }_{i}+\beta_{2} \text { Voting }_{i}+e_{i}
$$

where the dependent variable VoterSupport can represent the percentage of 'yes' votes on Measure C, percentage of 'yes' votes on Measure D, or the difference between support for Measure C and Measure 
D. Vote data was retrieved from San Diego Registrar of Voters (2018) at the voting precinct level, and aggregated up to the zip code level using precinct maps from the County of San Diego. ${ }^{1}$

Population includes various demographic characteristics representing the preferences of the median voter. These variables were chosen based on the previous literature and concerns raised in public debate over the measures. Variables include per capita income; population (log); median home value; the percentage of the population that is foreign-born, white, and male; a dummy variable, equal to one if the zip code contained the proposed stadium/convention center or was adjacent to it; and average commute time.

All demographic data was obtained from the American Community Survey (ACS 2011-2015 five-year data profiles) at the zip code level. Per capita income, median home value, and population are used to control for zip code size and income differences. Foreign-born population is included, due to San Diego's proximity to the border between Mexico and the United States, and potential preference differences for professional football versus other sports, such as soccer. The motivation for average commute time comes from the work of Humphreys and Pyun (2018) on congestion, related to professional baseball games. Proximity is used because of its usage in similar research on stadium finance voting and the potential externalities related to living near a professional sports stadium (Coates and Humphreys 2006). Percentage of the population that is white and male provide further demographic controls, possibly related to preferences for professional football. The correlation between more $\%$ male and proximity to the proposed stadium is 0.52 .

Voting includes the percentage of voters who voted for Donald Trump in the presidential election and voter turnout rate, both from the same time as Measures $C$ and D. These two additional variables, from San Diego Registrar of Voters (2018), were added to address voter preferences and engagement. The percentage of the votes for Donald Trump in the presidential election is included to control for any possible partisan views on public financing of sports stadiums. The variation on this variable across zip codes ranges from $9.41 \%$ to $46.72 \%$. Voter turnout-that is, the percentage of registered voters that voted in the election-is added to deal with differences in voter engagement and interest across zip codes. Voter turnout is correlated with per capita income at 0.76 . Voter turnout can be important, due to the fact that low turnout can lead to a greater special interest influence (Dunne et al. 1997; Meredith 2009). Summary statistics are shown in Table 1.

Table 1. Summary Statistics.

\begin{tabular}{lcccc}
\hline & Mean & Std. Dev. & Min & Max \\
\hline Percent Voted Yes on Measure C & 43.90 & 6.19 & 32.90 & 55.90 \\
Percent Voted Yes on Measure D & 41.18 & 5.22 & 33.66 & 51.72 \\
Difference Between Measure C \& D Support & 2.72 & 6.74 & -10.68 & 17.91 \\
Per Capita Income (000s) & 38.54 & 16.40 & 12.11 & 79.00 \\
Proximity & 0.21 & 0.41 & 0.00 & 1.00 \\
Population (log) & 10.21 & 0.74 & 7.31 & 11.09 \\
Percent of Population that is Foreign-born & 24.67 & 9.97 & 6.10 & 45.00 \\
Commute Time & 23.31 & 2.58 & 19.20 & 28.30 \\
Median Home Value (000s) & 544.32 & 244.30 & 253.20 & 1200.00 \\
Percent of Population that is White & 67.23 & 16.89 & 22.40 & 91.40 \\
Percent of Population that is Male & 50.27 & 2.97 & 45.30 & 59.20 \\
Percent Voted for Donald Trump & 28.08 & 9.97 & 9.41 & 46.72 \\
Voter Turnout Rate & 80.65 & 6.45 & 63.63 & 89.86 \\
\hline Observations & 34 & & & \\
\hline
\end{tabular}

1 Voting precincts do not perfectly map onto zip code boundaries, but very few precincts spanned multiple zip codes, thus measurement error is minimized. 


\section{Empirical Results}

Table 2 presents the results of our ordinary least-squares regressions, with percentage of 'yes' votes on Measure $\mathrm{C}$ as the dependent variable. The regressions are broken into three important parts. In column (1), the baseline results include population characteristics. Characteristics include population, median home value, per capita income, and the percentage of the population that is male, white, or foreign-born. This baseline reveals no significant results for any of the population characteristics at conventional levels. Proximity and commute time are added in column (2). Average commute time appears as a positive and significant variable. This is surprising, as traffic congestion was cited as a reason to oppose the measure, and Humphreys and Pyun (2018) showed that congestion is increased by professional sports. More congestion would presumably increase average commute time, but perhaps areas with longer commute times preferred to see the stadium located downtown and not elsewhere in the city.

Table 2. Regression Results: Percent Voted Yes on Measure C.

\begin{tabular}{llll}
\hline Variable & $\mathbf{( 1 )}$ & $\mathbf{( 2 )}$ & $\mathbf{( 3 )}$ \\
\hline Population (log) & $\begin{array}{l}-1.56725 \\
(-0.98)\end{array}$ & $\begin{array}{l}-1.37962 \\
(-1.00)\end{array}$ & $\begin{array}{l}-0.18548 \\
(-0.20)\end{array}$ \\
\hline Percent of Population that is Foreign-born & $\begin{array}{l}0.25765 \\
(1.80)\end{array}$ & $\begin{array}{l}0.11438 \\
(0.87)\end{array}$ & $\begin{array}{l}0.10184 \\
(1.01)\end{array}$ \\
\hline Percent of Population that is White & -0.01542 & -0.00323 & $0.12049 *$ \\
& $(-0.19)$ & $(-0.04)$ & $(2.38)$ \\
\hline Percent of Population that is Male & -0.00089 & 0.58415 & 0.53991 \\
& $(-0.00)$ & $(1.48)$ & $(1.69)$ \\
\hline Median Home Value (000s) & -0.00665 & -0.00653 & -0.00781 \\
\hline Per Capita Income (000s) & $(-0.58)$ & $(-0.65)$ & $(-1.16)$ \\
\hline Proximity & 0.00239 & 0.02519 & 0.14425 \\
& $(0.01)$ & $(0.17)$ & $(1.13)$ \\
\hline Commute Time & & -3.33682 & -1.91676 \\
\hline Percent Voted for Donald Trump & & $(-1.30)$ & $(-1.14)$ \\
\hline Voter Turnout Rate & & $1.33486 * *$ & $0.98432 * *$ \\
& & $(3.18)$ & $(3.29)$ \\
\hline Observations & & & $0.46407 * * *$ \\
\hline
\end{tabular}

Notes: ${ }^{*}: p<0.1{ }^{* *}: p<0.05 ;{ }^{* * *}: p<0.01 . t$ statistics in parentheses. Constant included, but not reported.

In the final column of Table 2, variables regarding political affiliation and voter turnout rate are added. Each voting variable is significant, with zip codes with higher support for Trump being more likely to support Measure C. A higher voter turnout rate was associated with less support of Measure C.

Support for Measure D was tested using the same process as Measure C, with results being displayed in Table 3. The baseline results for Measure D support indicate that the percent of the population that is foreign-born and the percent male are significant and positive, while per capita income is significant and negative. These results hold when adding proximity and commute time in column (2), but lose significance when adding voting variables. Upon adding the voting variable in column (3), voting on Measure D is very different; with the only similarity being that zip codes with higher voter turnout were less likely to vote for the measure. Areas with more Trump voters were 
less likely to vote in support of Measure $\mathrm{D}$, all other things being equal. This is surprising, given that Measure D was colloquially known as the "Citizens' plan" for its seemingly pro-taxpayer provisions and constraints on public financing of stadium construction, especially as compared to Measure C. However, Measure D still involved a tax increase and expansion of the convention center, which are two of the reasons why it was opposed by the San Diego County Taxpayers Association.

When compared to voting on Measure $C$, our results suggest that Trump voters were against tax increases for these public projects; but, if taxes were going to be raised, they wanted the Chargers to be part of the deal. That is why it is important to remember that these coefficients represent the effect of the variable holding everything else constant and one of the biggest differences between Measure $\mathrm{C}$ and Measure $\mathrm{D}$ was the restriction on public funding of sports stadiums without explicit voter approval through a referendum. The final interesting thing to note from the vote on Measure $\mathrm{D}$ is that proximity to the expanded convention center/home of the Chargers under Measure $\mathrm{C}$ is negatively related to voting 'yes' on Measure D.

Table 3. Regression Results: Percent Voted Yes on Measure D.

\begin{tabular}{|c|c|c|c|}
\hline & (1) & (2) & (3) \\
\hline Population (log) & $\begin{array}{l}-0.621 \\
(-0.73)\end{array}$ & $\begin{array}{l}-0.547 \\
(-0.64)\end{array}$ & $\begin{array}{l}-0.504 \\
(-1.22)\end{array}$ \\
\hline Percent of Population that is Foreign-born & $\begin{array}{l}0.257^{* *} \\
(3.36)\end{array}$ & $\begin{array}{l}0.217 * \\
(2.68)\end{array}$ & $\begin{array}{l}0.038 \\
(0.86)\end{array}$ \\
\hline Percent of Population that is White & $\begin{array}{l}0.049 \\
(1.11)\end{array}$ & $\begin{array}{l}0.049 \\
(1.10)\end{array}$ & $\begin{array}{l}-0.011 \\
(-0.51)\end{array}$ \\
\hline Percent of Population that is Male & $\begin{array}{l}0.602 \text { ** } \\
(3.06)\end{array}$ & $\begin{array}{l}0.719 \text { ** } \\
(2.95)\end{array}$ & $\begin{array}{l}0.072 \\
(0.51)\end{array}$ \\
\hline Median Home Value (000s) & $\begin{array}{l}0.001 \\
(0.21)\end{array}$ & $\begin{array}{l}0.001 \\
(0.18)\end{array}$ & $\begin{array}{l}-0.005 \\
(-1.76)\end{array}$ \\
\hline Per Capita Income (000s) & $\begin{array}{l}-0.213 * \\
(-2.31)\end{array}$ & $\begin{array}{l}-0.201 \text { * } \\
(-2.15)\end{array}$ & $\begin{array}{l}0.020 \\
(0.35)\end{array}$ \\
\hline Proximity & & $\begin{array}{l}-0.322 \\
(-0.20)\end{array}$ & $\begin{array}{l}-1.677^{*} \\
(-2.24)\end{array}$ \\
\hline Commute Time & & $\begin{array}{l}0.372 \\
(1.43)\end{array}$ & $\begin{array}{l}0.125 \\
(0.93)\end{array}$ \\
\hline Percent Voted for Donald Trump & & & $\begin{array}{l}-0.316^{\text {****}} \\
(-8.57)\end{array}$ \\
\hline Voter Turnout Rate & & & $\begin{array}{l}-0.258 * \\
(-2.36)\end{array}$ \\
\hline Observations & 34 & 34 & 34 \\
\hline$R^{2}$ & 0.719 & 0.740 & 0.949 \\
\hline
\end{tabular}

With results differing between support for Measure C and Measure D, the within-zip code difference between voting on Measures $C$ and $D$ is tested. The difference between support for Measures $\mathrm{C}$ and D possibly captures fans of the San Diego Chargers. The results shown in Table 4 indicate that areas with longer commute times had a greater differential (votes for Measure $C$ higher than Measure D).

Given that the reversion level was the Chargers possibly staying in Qualcomm, instead of leaving for Los Angeles, this could reflect that many suburban commuters did not want to commute downtown to attend Chargers games. Areas with a higher percentage of white voters had a preference for Measure $C$ over $D$, all other things being equal. Trump voters overwhelmingly preferred $C$ to D. Finally, zip codes with a higher voter turnout saw the difference between votes on Measure $C$ and D shrink. Given 
the negative coefficients on voter turnout in the Measure C and Measure D specifications, this finding seems to confirm that higher voter turnout is bad for publicly-funded stadiums. This is consistent with the literature on low voter turnout being better for clearly-defined groups, such as Chargers fans (Anzia 2011; Dunne et al. 1997; Meredith 2009).

Table 4. Regression Results: Difference Between Measure C and Measure D.

\begin{tabular}{|c|c|c|c|}
\hline & (1) & (2) & (3) \\
\hline Population (log) & $\begin{array}{l}-0.946 \\
(-0.50)\end{array}$ & $\begin{array}{l}-0.832 \\
(-0.45)\end{array}$ & $\begin{array}{l}0.319 \\
(0.38)\end{array}$ \\
\hline Percent of Population that is Foreign-born & $\begin{array}{l}0.000 \\
(0.00)\end{array}$ & $\begin{array}{l}-0.103 \\
(-0.59)\end{array}$ & $\begin{array}{l}0.064 \\
(0.69) \\
\end{array}$ \\
\hline Percent of Population that is White & $\begin{array}{l}-0.064 \\
(-0.66)\end{array}$ & $\begin{array}{l}-0.052 \\
(-0.54)\end{array}$ & $\begin{array}{l}0.132 \text { ** } \\
(2.86)\end{array}$ \\
\hline Percent of Population that is Male & $\begin{array}{l}-0.603 \\
(-1.38)\end{array}$ & $\begin{array}{l}-0.135 \\
(-0.26)\end{array}$ & $\begin{array}{l}0.467 \\
(1.60)\end{array}$ \\
\hline Median Home Value (000s) & $\begin{array}{l}-0.008 \\
(-0.58)\end{array}$ & $\begin{array}{l}-0.008 \\
(-0.57)\end{array}$ & $\begin{array}{l}-0.003 \\
(-0.41)\end{array}$ \\
\hline Per Capita Income (000s) & $\begin{array}{l}0.215 \\
(1.05)\end{array}$ & $\begin{array}{l}0.226 \\
(1.12)\end{array}$ & $\begin{array}{l}0.125 \\
(1.07)\end{array}$ \\
\hline Proximity & & $\begin{array}{l}-3.015 \\
(-0.88)\end{array}$ & $\begin{array}{l}-0.240 \\
(-0.16)\end{array}$ \\
\hline Commute Time & & $\begin{array}{l}0.963 \\
(1.72) \\
\end{array}$ & $\begin{array}{l}0.860 * * \\
(3.15)\end{array}$ \\
\hline Percent Voted for Donald Trump & & & $\begin{array}{l}0.780^{* * *} \\
(10.37)\end{array}$ \\
\hline Voter Turnout Rate & & & $\begin{array}{l}-0.664^{* *} \\
(-2.97)\end{array}$ \\
\hline Observations & 34 & 34 & 34 \\
\hline$R^{2}$ & 0.172 & 0.272 & 0.872 \\
\hline
\end{tabular}

The results in Table 4 highlight the importance of the timing of the referenda. Had the referenda been included in an election that induced a lower voter turnout rate than the 2016 US presidential election, San Diego Chargers fans could have dictated the outcome of the results.

\section{Conclusions}

The San Diego Chargers are now the Los Angeles Chargers. This is, in no small part, due to the failure of the Chargers to secure public financing for a new stadium in downtown San Diego through Measure C. Using zip code-level voting data, we find that areas with more Trump voters were in favor of public subsidies for the Chargers. When looking at the vote on Measure D which prevented public funding from going to sports stadiums, we find that Trump voters were against higher taxes for only an expanded convention center.

Our other important finding is the importance of voter turnout. Zip codes with higher turnout were less likely to vote for Measures C and D. Dunne et al. (1997), among others, showed how low voter turnout enhanced the ability of special interests to get their preferred policies passed at the ballot box. Our results are consistent with this literature and highlight how the timing of these measures-that is, being at the same time as a Presidential election-likely depressed the percentage voting in favor of each measure. Given that Measure $C$ required the approval of two-thirds of the voters to become law (a requirement in California for tax increases that have a specific use), the higher voter turnout likely 
influenced the outcome. In other settings, however, the timing of stadium funding referenda might matter for the eventual outcome.

Author Contributions: Writing—original draft, C.J.; Writing—review \& editing, J.H.

Funding: This research received no external funding.

Conflicts of Interest: The authors receive no funding for this paper. During his career, Joshua Hall has received funding from the Charles Koch Foundation, the Thomas Smith Foundation, the Alliance for Markets Solutions, the Institute for Humane Studies, Liberty Fund, and over 30 colleges and universities. Candon Johnson has received funding from the Institute for Humane Studies through the Hayek Fund.

\section{References}

Ahlfeldt, Gabriel, and Wolfgang Maennig. 2012. Voting on a NIMBY facility: Proximity cost of an "iconic" stadium. Urban Affairs Review 48: 205-37. [CrossRef]

Anderson, Erik. 2016. Measure D: Citizens' plan coming up short. KBPS, November 9.

Anzia, Sarah F. 2011. Election timing and the electoral influence of interest groups. Journal of Politics 73: 412-27. [CrossRef]

Baade, Robert A. 1996. Professional sports as catalysts for metropolitan economic development. Journal of Urban Affairs 18: 1-17. [CrossRef]

Bonesteel, Matt. 2016. Chargers' stadium vote fails miserably, clouding future in San Diego. San Diego Union-Tribune, November 9.

Brown, Clyde, and David M. Paul. 1999. Local organized interests and the 1996 Cincinnati sports stadia tax referendum. Journal of Sport and Social Issues 23: 218-37. [CrossRef]

Cate, Chris, April Boling, and Julie Meier Wright. 2016. How a Chargers stadium jeopardizes San Diego Comic-Con. San Diego Union-Tribune, August 25.

Chapin, Tim. 1999. The political economy of sports facility location: An end-of-the-century review and assessment. Marquette Sports LJ 10: 361.

Chase, Chris. 2015. Ranking the best and worst NFL stadiums, from no. 1 (Lambeau) to 31 (Soldier). USA Today, October 16.

Chavez, Chris. 2018. Report: Rams, Chargers stadium to cost almost \$5 billion. Sports Illustrated, March 27.

Coates, Dennis, and Brad R. Humphreys. 2003a. The effect of professional sports on earnings and employment in the services and retail sectors in us cities. Regional Science and Urban Economics 33: 175-98. [CrossRef]

Coates, Dennis, and Brad R. Humphreys. 2003b. Professional sports facilities, franchises and urban economic development. Public Finance and Management 3: 335-57.

Coates, Dennis, and Brad R. Humphreys. 2006. Proximity benefits and voting on stadium and arena subsidies. Journal of Urban Economics 59: 285-99. [CrossRef]

Coates, Dennis, and Brad R. Humphreys. 2008. Do economists reach a conclusion on subsidies for sports franchises, stadiums, and mega-events? Econ Journal Watch 5: 294-315.

Coates, Dennis, and Pamela Wicker. 2015. Why were voters against the 2022 Munich Winter Olympics in a referendum? International Journal of Sport Finance 10: 267.

Dunne, Stephanie, W Robert Reed, and James Wilbanks. 1997. Endogenizing the median voter: Public choice goes to school. Public Choice 93: 99-118. [CrossRef]

Friedman, Michael T., and Daniel S. Mason. 2004. A stakeholder approach to understanding economic development decision making: Public subsidies for professional sport facilities. Economic Development Quarterly 18: 236-54. [CrossRef]

Garrick, David. 2016. SD stadium measures both trailing badly. San Diego Union-Tribune, November 9.

Hall, Joshua C., and Serkan Karadas. 2018. Tuition increases Geaux away? Evidence from voting on Louisiana's amendment 2. Applied Economics Letters 25: 924-27. [CrossRef]

Hazinski, Thomas, and Jorge Cotte. 2016. Report on Proposed Joint Development of a Stadium-Convention Center: Chargers Stadium-Convention Center. Chicago: HVS Convention, Sports \& Entertainment Facilities Consulting.

Holcombe, Randall G. 1989. The median voter model in public choice theory. Public Choice 61: 115-25. [CrossRef]

Holcombe, Randall G., and Lawrence W. Kenny. 2008. Does restricting choice in referenda enable governments to spend more? Public Choice 136: 87-101. [CrossRef] 
Horn, Brady P., Michael Cantor, and Rodney Fort. 2015. Proximity and voting for professional sporting stadiums: The pattern of support for the Seahawk stadium referendum. Contemporary Economic Policy 33: 678-88. [CrossRef]

Humphreys, Brad. 2019. Should the construction of new professional sports facilities be subsidized? Journal of Policy Analysis \& Management 38: 264-70.

Humphreys, Brad R., and Hyunwoong Pyun. 2018. Professional sporting events and traffic: Evidence from US cities. Journal of Regional Science 58: 869-86. [CrossRef]

Lewis, Scott. 2015. The genius of-and the problem with-the Briggs hotel-tax overhaul. Voice of San Diego, November 10.

Matheson, Victor. 2019. Is there a case for subsidizing sports stadiums? Journal of Policy Analysis E Management 38: 271-77.

Matti, Joshua, and Yang Zhou. 2017. The political economy of Brexit: Explaining the vote. Applied Economics Letters 24: 1131-34. [CrossRef]

McSwain, Dan. 2016. San Diego hoteliers find a little to like, plenty to hate with Measure D. San Diego Union-Tribune, November 4.

Meredith, Marc. 2009. The strategic timing of direct democracy. Economics E Politics 21: 159-77.

Nelson, Kevin. 2016. Measure C goes to the ballot for a major vote. The Vista (University of Central Oklahoma), October 6.

Nunn, Samuel, and Mark S. Rosentraub. 1997. Sports wars: Suburbs and center cities in a zero-sum game. Journal of Sport and Social Issues 21: 65-82. [CrossRef]

Peach, James. 2004. Thorstein veblen, ty cobb, and the evolution of an institution. Journal of Economic Issues 38: 326-37. [CrossRef]

Pelissero, Tom. 2017. Awkward spot, awkward solution for Chargers in LA move. USA Today, January 12.

Rosentraub, Mark S. 1996. Does the emperor have new clothes? A reply to robert j. baade. Journal of Urban Affairs 18: 23-31. [CrossRef]

San Diego City Attorney. 2016. City's Attorney's Impartial Analysis and Fiscal Impact Statement. San Diego: San Diego Registrar of Voters.

San Diego Registrar of Voters. 2018. Election Results. San Diego: San Diego Registrar of Voters.

Schrotenboer, Brent. 2016. Stadium vote may define Chargers' future; two-thirds needed to raise hotel tax, but getting a majority would bode well. USA Today, November 8 .

Showley, Roger. 2016. Taxpayers group opposes Briggs hotel-tax hike. San Diego Union Tribune, August 23.

Sklar, Debbie. 2016. Stadium ballot arguments focus on jobs, future events, tourism and priorities. Times of San Diego, August 26.

(C) 2019 by the authors. Licensee MDPI, Basel, Switzerland. This article is an open access article distributed under the terms and conditions of the Creative Commons Attribution (CC BY) license (http://creativecommons.org/licenses/by/4.0/). 